\title{
Rhetorical Conventions in the Conclusion Genre: Comparing English and Persian Research Articles in the Field of Social Studies
}

\author{
Omid Tabatabaei
}

Assistant Professor, Najafabad Branch, Islamic Azad University, Najafabad, Iran

Leila Azimi

MA in TEFL, Najafabad Branch, Islamic Azad University, Najafabad, Iran

\author{
Doi:10.5901/mjss.2015.v6n6s1p372
}

\section{Abstract}

\begin{abstract}
The present study examined the generic structure of the conclusion section of English and Persian Research Articles (RAs) in the field of social studies with the aim of investigating the difference between the two languages. To do so, 50 English and Persian conclusions written and published in credible leading journals were analyzed based on Yang and Allison (2003) model. Results revealed that although there was a kind of unity between the two languages, there were differences between the two corpora. Regarding the frequency of the moves, English authors utilized Move 5 (i.e., Summarizing the study) and Step 2 of Move 6 (i.e., Indicating significance/ advantage) frequently; while, Persian authors used Move 2 (i.e., Reporting results) and Step 3 of Move 4 (i.e., Accounting for results) more. In addition, results showed that the least infrequent move and step in conclusion sections of English RAs were Move 4 (i.e., Commenting on results) and Step 4 of Move 4 (i.e., Evaluating results); whereas, the least frequent move and step in Persian conclusions were Move 7 (i.e., Deduction from the research) and Step 2 of Move 7 (i.e., Recommending further research). Regarding the sequence of moves, findings indicated that English authors tended to use Move 5 (i.e., Summarizing the study) as the opening move of the conclusion section; while, Persian authors utilized Move 1 (i.e., Back ground information) as the most prominent opening move.
\end{abstract}

Keywords: conclusion, research article, generic structure, genre, move, step

\section{Introduction}

Over the last two decades, having the knowledge of genre has been acknowledged because it is required to help language learners to understand and master academic, professional, and educational discourse (Swales, 2004). In recent years, there has been an increasing interest in studies of genre analysis. In the field of English for Specific Purposes (ESP), the best-known authors are John Swales and Vijay Bhatia (Flowerdew \& Wan, 2010). Their books (Bhatia, 1993, Swales, 1990) have currently influenced many research studies and they have been frequently cited in the research conducted in various disciplines.

Swales (1986) considered RAs as a genre and defined genre as a recognized event with a shared public purpose and communicative intentions which is a highly structured and standardized communicative event. This definition indicates that genre is based on the intent, positioning, form and functional value of the participants. In fact, it is something that makes them understand each other. Describing genre as a social action developed a new discipline in text analysis which Miller (1994) called Rhetorical Genre Studies (RGS). Benedict (2006) claimed that genre-based approaches should be based on both semantic micro-functions of individual words as well as social macro purposes of languages.

Several studies have been done based on genre analysis approach to compare different sections of RAs in two or more languages. For instance, Swales (1990) investigated move structure in the 'Introduction' section of ESP RAs. In a similar study, Salager-Meyer (1992) examined 'Abstracts'. Thompson (1993), Brett (1994) and Lim (2006) studied the 'Results' sections. In addition, Holmes (1997) and Hopkins and Dudley-Evans (1988) investigated the 'Discussion' section, the former in Sociology and Political Sciences History and the latter in RAs in general.

Such studies have shown that although writing conventions are common among most languages, the rhetorical moves that constitute the generic structure of an article are different from one language like English to another such as Persian depending on the field of study. Moves and steps are the units of analysis in the present study proposed by Swales (1990). As McKinley (1983) stated, moves are semantic units which have linguistic features with a uniform 
purpose and content (Nwogu, 1997). Each unit has specific function by which the writer can highlight based on special communicative intention it involves. Not only does each genre have a special language in relation to other genres, but also each move contains a specific language which is applied in specific conditions. In this situation, when a Persian writer in Social Studies wants to write an English research article, a similar genre will be used. Nevertheless because of differences between the two languages, it is possible for applied moves and steps not to be identical.

In an Iranian context, Habibi (2008) studied the introduction section in RAs of the three related fields, namely English for Specific Purposes (ESP), Psycholinguistics, and Sociolinguistics, using John swales ' The Create a Research Space (CARS) model. The results of the analysis showed clear differences between the disciplines about Move 2/step 1B, but no differences in introduction sections across the disciplines of Move 1 and 3 along with their constituent steps. They found no difference in the extent of concordance between CARS and the move structure of the RAs analyzed.

However, one of the main parts of a RA is 'Conclusion' in which the writer states his or her concluding remarks. It is a common practice for readers to go to the conclusion before reading all parts of an article. This is mainly done to save time and make a decision to whether they should read the other parts of the article. The 'Conclusion' section is the last part of the article in which the writer has the opportunity to refer to the main topic and variables, reiterating the most important points, summarizing all related research, and presenting the findings of the article. Therefore, the writer should finish it in an effective way that satisfies the readers to follow all parts of the article.

Regarding the importance of 'Conclusion' in research articles, the writer should have high capability to write in a way that it affects readers' mind to direct their ideas. Because of the value of being aware of the rhetorical organization of a research article, especially in 'Conclusion' and having competence to use it, it will be a requirement to investigate the generic structure of the conclusion section. As can be seen, the rhetorical structure of RAs by native and non-native speakers is different. Therefore, the present study has focused on the 'Conclusion' sections of RAs produced and published in English journals by native English writers and Persian articles published in Persian journals. The study was intended to identify rhetorical differences between the two languages. Specifically, the conclusion section of RAs in Social Studies was selected; the researcher hoped to provide some empirical solution to the problems of genre differences in English and Persian Social Studies research articles.

\section{This Study}

Based on what has been mentioned, the present study was intended to compare the rhetorical structure of the Conclusions section of RAs published by Persian writers in Persian journals with the ones by English writers published in English journals. In addition, this study sough to identify rhetorical preferences used by Persian and English native speaker writers from two different scientific communities. To achieve these aims, the following research question and hypothesis are formulated.

RQ: Is there any significant difference between Persian and English rhetorical moves that constitute the generic structure of conclusion section of social studies research articles developed by such writers?

$\mathrm{H}_{0}$ : There is no significant difference between Persian and English writers in making use of the rhetorical moves that constitute the generic structure of conclusion section of social studies research articles.

\section{Method}

\subsection{Corpus of Research Articles in Social Studies}

A corpus of 50 conclusions extracted from RAs were used in this research. It included 25 Persian and 25 English RAs in Social Studies taken from leading international journals.

In order to select the journals first a comprehensive list of journals published in Social Studies in both languages was collected through net surfing and searching references in university libraries. Then the most standard journals identified by the experts in this field were selected through stratified sampling procedure. Based on the importance, relevance, and reputation of the journals, the research-oriented RAs were drawn from unequal-sized samples. Eventually, several English (Table 1) and Persian (Table 2) journals were selected for the purpose of this study

It should be noted that RAs with certain features were selected. In fact, all the RAs were supposed to contain standard sections of a research article, i.e. 'Introduction', 'Method', 'Results', 'Discussion,' and' Conclusion' or just conclusion with one to seven paragraphs. Moreover, in order to find papers written by English native speaker scholars, the nationality of the authors was identified based on their place of birth written at the end of articles or through searching the internet. Meanwhile the corpus was restricted to a period of time approximately four years to control changes in any of 
two languages. Therefore, journals published between 2010 and 2014 were preferred. Tables 3.1 and 3.2 summarize information about English and Persian journals along with the number of conclusion sections.

Table 1. Details of the English Social Studies Research Articles Corpus

\begin{tabular}{|c|c|c|c|}
\hline Journal & Field & Writer's Language & Number of Conclusion Section \\
\hline Social Studies & & English & 1 \\
\hline Leadership Quarterly & & & 6 \\
\hline Child Abuse Neglect & & & 6 \\
\hline Procedia Social and Behavioral Sciences & & & 2 \\
\hline Journal of Adolescent Health & & & 1 \\
\hline Journal of Rural Studies & & & 1 \\
\hline Science Direct & & & 1 \\
\hline Aggression and Violent Behavior & & & 1 \\
\hline Journal of Social Sciences & & & 1 \\
\hline Advances in Life Course Research & & & 1 \\
\hline Social Science \& Medicine & & & 1 \\
\hline American Sociological Association & & & 1 \\
\hline Children and Youth Services Review & & & 1 \\
\hline Climate risk management & & & 1 \\
\hline Energy procedia & & & 1 \\
\hline
\end{tabular}

Table 2. Details of the Persian Social Studies Research Articles Corpus

\begin{tabular}{|c|c|c|c|}
\hline Journal & Field & Writer's language & Number of Conclusion Section \\
\hline Social studies & & Persian & 3 \\
\hline مجله علوم اجتماعى دانشحاه فردوسى مشهد & & & 1 \\
\hline فصلنامه علمى يُزو هشى زن در توسعه وسياست & & & 5 \\
\hline مجله علم يُزو هشى جامعه شناسى كاربردى & & & 1 \\
\hline فصلنامه علمى يزّ هشى رفاه اجتماعى & & & 1 \\
\hline فصلنامه بُزو هش و برنامه ريزى در آموزش عالى & & & 1 \\
\hline فصلنامه علمى بزّو هشى رو انشناسى و دين & & & 1 \\
\hline فصلنامه تحقيقات فرهنگى & & & 1 \\
\hline فصلنامه زن و جامعه & & & 1 \\
\hline 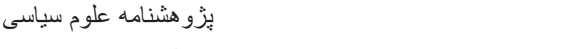 & & & 1 \\
\hline فصلنامه علمى بزّو هشى علوم اجتماعى دانشگاه علامه طباطبايى & & & 1 \\
\hline فصلنامه بِزو هش هاى راهبردى امنيت و نظم اجتماعى & & & 3 \\
\hline فصلنامه مطالعات امنيت اجتماعى & & & 2 \\
\hline فصلنامه مطالعات مديريت انتظامى & & & 1 \\
\hline فصلنامه علمى بِزو هشى برنامه ريزى رفاه و توسعه اجتماعى & & & 3 \\
\hline
\end{tabular}

\subsection{Procedures}

There were several stages taken to analyze the data. The first stage was identification of the conclusion section of the articles through searching the final section of each 50 RAs. Nevertheless, because authors used different frameworks in writing research articles, there were different sections in different research articles. For instance, the proposed framework by some studies (e.g., Brett, 1994; Holmes, 1997; Swales, 1990) included Introduction, Method, Result and Discussion while some other researches (e.g., Graetz, 1985; Salager-Mayer, 1990, 1992; Ventola, 1992) include the alternative section of Conclusion instead of Discussion. Also, some of the articles involved both Discussion and Conclusion section and in some others the three sections of the Discussion and Conclusion and Results were included in one part.

As Holmes (1997) and also Yang and Allison (2003) believed, although these parts are mixed in some cases, their 
communicative purposes are different. In the Result section, the results of the study are stated while Discussion focuses on commenting, interpreting, evaluating and comparing the results with previous works. Similarly, Conclusion usually indicates a summary of the research, its findings, some guidelines for further research as well as its implications for the related field.

Regarding the above mentioned points and the purpose of this study, Discussion and Conclusion were considered as two different parts with different functions. Therefore, Conclusion was discriminated from Discussion in each article based on its conventional and functional headings like the title "Conclusion" or certain concluding statements following the communicative purposes of the section. After this stage a corpus of 25 research articles conclusion were left for analysis in each language.

In the second stage, the move structures showing the author's intention in the conclusion section of articles in Social Studies was identified. The Moves concept was introduced for the first time by Swales (1990) in an analytical framework called the CARS model. Swales defined move as a "discoursal or rhetorical unit that performs a coherent communicative function in a written or spoken discourse". This model was used to base move analysis of the corpus through which the textual boundaries between moves were identified. McKinley (1983) defined Move as a semantic unit related to the purpose of the writer. Also Nwogu (1997) described it as a text segment consisting of linguistic features with uniform orientation in which the boundary of each move is identified from the other based on the content, semantic, and linguistic features of text with a particular function. Considering the above-mentioned definitions, the criterion for move identification was adapted based on Nwogu's definition of move, namely content, semantic, and linguistic units. Therefore, the Move-Step method was considered as the unit of data analysis.

In order to use this method to analyze the conclusion sections, it was necessary to know how to recognize the steps in a move. Based on this model, when several texts were compared with each other, the unit of analysis was the sentence. This implied that a move was equivalent to a sentence. Moreover, each move was a segment often consisting of one or more steps along with a general function. Each step involved some more special rhetorical features which complete the function of related moves. As Holmes (1997) believed, to analyze a single text or a segment of a text, the unit of analysis was below the level of sentence. This implied that a move was smaller than a sentence or a sentence contained two moves. Therefore, following Ozturk (2007), the more salient moves were selected. In most cases, a move was equal to a sentence as the unit of analysis.

In the third stage, the reliability of the research was examined. There was not a fixed unit to identify the moves easily and it was somehow subjective. Therefore, in order to increase the reliability of the research, two other raters were asked to check the corpora independently and the results were compared. Two academic experts who were professional in genre analysis of RA were selected. Finally, for the beginning of the analysis Yang and Allison's (2003) model was applied.

\subsection{Yang and Allison (2003) Model}

Yang and Allison (2003) Proposed a Model for Conclusion Sections of Academic Research Articles. This model was used in the present study in order to analyze the data.

- Move 1: Background Information

- Move 2: Reporting Results

- Move 3: Summarizing Results

- Move 4: Commenting on Results

- Step 1: Interpreting results

- Step 2: Comparing/Contrasting results with literature

- Step 3: Accounting for results

- Step 4: Evaluating results

- Move 5: Summarizing the Study

- Move 6: Evaluating the Study

- Step 1: Indicating limitations

- Step 2: Indicating significance/advantage

- Step 3: Evaluating methodology

- Move 7: Deductions from Research

- Step 1: Making suggestions

- Step 2: Recommending further research

- Step 3: Drawing pedagogic implications 


\subsection{Data Analysis}

In order to find out the similarities and differences of moves and steps identified in "Conclusion" of RAs in the two languages in Social Studies, the frequency of occurrence of each move and its constituent steps were calculated and a comparative generic analysis was carried out in all selected RAs.

After comparative analysis of the generic structure of Persian and English conclusions, the obtained data were analyzed. A Mann-Whitney test was utilized in order to find probable significant differences between applied moves in both groups of English and Persian authors in Social Studies. The Persian and English articles in the corpus were coded from P.1 to P25 for the Persian articles and from E.1 to E.25 for the English ones.

\section{Results and Discussion}

In order to analyze and compare the conclusion sections of two corpora, the total number of moves used in each RA was calculated. Then, all of the moves which was utilized in the conclusion sections of each corpus totally were analyzed both in Persian and English RAs. Afterwards, a Mann Whitney Test was conducted in order to compare the moves used in two languages RAs conclusions. In what follows, the differences between the two corpora based on the rhetorical moves and steps used in RAs are discussed in detail. Frequency and Percentage of the Moves in Persian and English RAs conclusions are presented in Table 3.

Table 3. Frequency and Percentage of the Number of All Moves in Persian and English RAs Conclusions

\begin{tabular}{lcccc}
\hline \multirow{2}{*}{ Number of used Moves } & \multicolumn{2}{c}{ English } & \multicolumn{2}{c}{ Persian } \\
\cline { 2 - 6 } No move & Frequency & percentage & Frequency & percentage \\
\hline One move & 0 & $\% 0$ & 0 & $\% 0$ \\
\hline Two moves & 1 & $\% 4$ & 0 & $\% 0$ \\
\hline Three moves & 1 & $\% 4$ & 0 & $\% 0$ \\
\hline Four moves & 9 & $\% 36$ & 2 & $\% 8$ \\
\hline Five moves & 5 & $\% 20$ & 7 & $\% 28$ \\
\hline Six moves & 2 & $\% 8$ & 7 & $\% 28$ \\
\hline All seven moves & 5 & $\% 20$ & 5 & $\% 20$ \\
\hline Total & 2 & $\% 8$ & 4 & $\% 16$ \\
\hline Mann-Whitney Test results: Z=-2.227 & $\mathbf{p}=\mathbf{0 . 0 2 6}$ & $\% 100$ & 25 & $\% 100$ \\
\hline
\end{tabular}

According to the results mentioned in Table 3, not only there was no RA in which the author has not used any move, but also all Persian RAs conclusions possessed more than two moves in all cases. In other words, Persian RAs of all social studies contained at least three or more moves in the conclusion sections. Most of Persian authors used four or five moves together (\%28 of RAs) in the conclusion sections. However, only \%16 of Persian RAs contained all seven moves together.

Moreover, Table 3 revealed that like Persian RAs, English authors tended to utilize moves in all RAs. However, \%4 of English RAs included only one or two moves. In contrast to Persian RAs in which moves were used frequently, English authors tended not to use moves as many as Persian RAs. The largest amount of moves used together in English RAs were three moves (\%36 of RAs totally). Furthermore, only \%8 of English RAs included all seven moves in conclusion sections.

The results of Mann Whitney test indicated that the significance of the test was less than .05. Therefore, the null hypothesis of the study predicting that there is no significant difference between Persian and English writers in making use of the rhetorical moves that constitute the generic structure of conclusion section of social studies research articles is rejected.

In order to investigate the difference between the two languages further, Table 4 presented the results of the sequence of moves in the two languages. 
Table 4. Results of Statistical Analysis of Moves in Persian and English Research Articles Conclusion.

\begin{tabular}{lccccl}
\hline & \multicolumn{2}{c}{ English } & \multicolumn{2}{c}{ Persian } & \multirow{2}{*}{ Variation Pattern } \\
\cline { 2 - 6 } Background Information & Frequency & percentage & Frequency & percentage & Persian>English \\
\hline Reporting Results & 9 & $36 \%$ & 18 & $72 \%$ & Persian>English \\
\hline Summarizing Results & 7 & $28 \%$ & 22 & $88 \%$ & Persian \\
\hline Commenting on Results & 9 & $36 \%$ & 21 & $84 \%$ & Persian>English \\
\hline Summarizing the Study & 10 & $40 \%$ & 24 & $96 \%$ & Persian>English \\
\hline Evaluating the Study & 21 & $84 \%$ & 19 & $76 \%$ & No difference \\
\hline Deductions from Research & 24 & $96 \%$ & 14 & $56 \%$ & Persian<English \\
\hline
\end{tabular}

As reported in Table 4, Persian authors tended to open the conclusion section with Move 1, namely "Back ground information", while the preferred move for opening conclusion in English RAs was Move 5, namely "Summarizing the study". Regarding the frequency of move 1 "Back ground information" in two languages, findings was revealed that Persian writers utilized the move two times more than English writers. It is possible that Persian writers like to acquaint the readers more with the subject of RA. The fundamental communicative move in Persian RAs conclusions was Move 2 "Reporting results"; while, this move was utilized in English RA conclusions rarely. In Persian RAs, Move 2 often cooccurred with Move 3 (Summarizing results) and Move 4 (Commenting on results) that is, first, results were presented in detail, and then the total results were stated and finally the results were to be commented upon. According to the results, the Persian authors used Move 3 "Summarizing results" frequently, although in English RAs the mentioned move was applied rarely.

Comparing Move 4 "commenting on results" and constituent steps in two languages in Table 4, the following results were gained. There was a significant difference between two languages in utilizing Move 4 . The mentioned move was frequently utilized in Persian RAs conclusions totally, but there was a little tendency in using the move in English RAs conclusions. Step 1 "Interpreting results" was used in Persian RAs conclusion repeatedly while, a few of English writers preferred to employ the step in RAs conclusions. The results showed that Persian and English authors utilized Step 2 "Comparing results with literature". However, the amount of usage was more in Persian RAs conclusions. Considering total steps of Move 4, Step 2 was used more than others in English RAs. In spite of the fact that English authors didn't prefer to use Step 3 "Accounting for results", the mentioned step was the most repeated one in Persian RAs conclusions. Also Step 3 was the most utilized one among the four steps of Move 4 in Persian RAs conclusions. There was a similarity between two languages in Step 4: "Evaluating result" in which the amount of using the step was negligible. Moreover, the two languages were similar in using Move 5, namely "Summarizing the study", with parallel frequency. In the two languages the move was utilized frequently.

In the analysis of Move 6 "Evaluating the study" and component steps following results were attained. Totally, Persian authors didn't show noticeable inclination to use Move 6 in RAs conclusions, whereas in most of the English RA conclusions, Move 6 was used frequently. Nevertheless, there were some similarities in using steps of Move 6 in the two languages. Step 1 "indicating limitation" was considered as an infrequent one among all three steps in both Persian and English RAs conclusions. In contrast to Step 1, Step 2 "indicating significance advantage" was the most frequent one between all three steps of Move 6 in the two languages. Step 3 "Evaluating methodology" was the least frequent one between the three steps in both Persian and English RA conclusions.

Moreover, Move 7 "Deduction from research" and the steps were analyzed in Table 4 and the results revealed as follows. Generally, Move 7 was not considered significantly by Persian authors in writing conclusion sections of RAs, whereas there was a significant tendency to utilize Move 7 in writing English RAs conclusions. The similarity of the two languages was in using Step 1 "Making suggestion" which in both Persian and English RA conclusions was utilized more than other steps of the move. It can be concluded from the results that Step 2 "Recommending further research" was the most infrequent one between three steps of Move 7 in both Persian and English RA conclusions. The frequency of Step3 of Move 7 "Drawing pedagogic implication" was equal to Step1 in Persian RAs conclusions (\%24), and equal to Step 2 in English RAs conclusion (\%52).

\section{Conclusion}

Based on the discussion of the findings in can be concluded that in spite of the existence of general unity in the moves across the two languages, there were significant differences in the frequency and the sequence of moves in the two 
languages.

The obtained findings can be useful for scholars who seek to have publications in English. These results may persuade non-native students and scholars to produce more written works and publishable research articles, instead of merely using published texts in international journals. Along with the development of writing skills through genre knowledge, the scholar's self-confidence to write a publishable RA in leading journals increases. Therefore, the motivation to do further research will increase.

Another issue us that international publishing for authors in countries like Iran, where English is not the native language, needs more cross-cultural studies of academic genres and disciplines. This way the employed rhetorical structures in two languages are explained more specifically. Consequently, the difficulties of writing RAs in English, which non-native writers are faced with, are reduced.

Additionally, the results of the present study can develop writing pedagogy both in primary and advanced academic levels. There are several deficiencies in the educational system of Iran for teaching foreign languages especially in teaching writing skill. Concerning these problems in Iran, the finding of the present study, which is related to genre knowledge and rhetorical moves used in RAs, can assist curriculum designers to plan a class syllabus describing all types of genre and the rhetorical moves utilized both in English and Persian.

Like all other studies the present work had limitations. First, since the size of the corpus or the number of articles was limited, the findings of the study may not be generalized to the total population of academic authors. Therefore, the statistical verification of the observed results may not to be accurate precisely and only some tentative conclusions can be proposed. Second, the other limitation of the present study is investigating only a single discipline i.e., social studies RAs. Furthermore, the study was confined to focus only on the conclusion sections of RAs. In addition, since the present study could not have access to the individual authors of each research article, the nationality of the authors might be in question. It was impossible to find the origins or the cultures of authors.

There are a few suggestions for future research which are as follows. First, in order to do more comprehensive studies, it is suggested to analyze not only the conclusion section, but also all sections of the RAs. The advantage of such research like Nwogu (1997) and Kanoksilapatham (2005), which analyzed complete RAs in medicine and biochemistry, is that the structural relation of each section to other sections and also to the overall textual organization of the RA will be apparent. Also, such a holistic study can determine how the sections are related to each other.

In addition, further investigation can be done with regard to other aspects of genre analysis. For instance, future works can examine if there is a kind of hybridity in writing of different genres of Persian language compared to English language or not. Such studies can assist novice EFL students and non-native scholars to acquaint with the academic writing based on English conventions in international journals. Finally, the present study investigated the textual features of rhetorical moves of the Conclusion section. It would have been more efficient for future studies to also focus on textual meta-functions of the conclusion section as well as other sections of RAs.

\section{References}

Benedict, L. (2006). Genre-based teaching and Vygotskian principled in EFL: The case of a university writing course. Singapore: Nanyang Technological University.

Bhatia, V. K. (1993). Analyzing genre: Language use in professional settings. New York: Longman Publishing.

Brett, P. (1994). A genre analysis of the Results section of sociology articles. English for Specific Purposes, 11, 33-49.

Flowerdew, J., \& Wan, A. (2010). The linguistic and the contextual in applied genre analysis: The case of the company audit report, English for Specific Purposes, 29, 78-93.

Graetz, N. (1985). Teaching EFL students to extract structural information from Abstracts. In J. M. Ulign, \& A. K. Pugh (Eds.), Reading for professional purposes: Methods and materials in teaching languages (pp. 123-135).Leuven: Acco.

Habibi, P. (2008). Genre analysis of research article Introductions across ESP, Psycholinguistics, and Sociolinguistics. IJAL, 11(2), 87111.

Holmes, R. (1997). Genre analysis and the social sciences: An investigation of the structure of research article Discussion sections in three disciplines. English for Specific Purposes, 16(4), 321-337.

Kanoksilapatham, B. (2005). Rhetorical structure of biochemistry research articles, English for Specific Purposes, 24, 269-292.

Lim, J. M. H. (2006). Method sections of management research article: A pedagogically motivated qualitative study. English for Specific Purposes, 25, 282-309.

McKinley, J. (1983). An analysis of Discussion sections in medical journal articles. Unpublished M.A. dissertation, University of Birmingham, UK,

Miller, C. R. (1994). Rhetorical community: The cultural basis of genre. In A. Freedman, \& P. Medway (Eds.), Genre and the New Rhetoric. London: Taylor and Francis.

Nwogu, I. (1997). Page to screen: Taking literacy in to the electronic era. London and New York: Routledge. 
Salager- Meyer, F. (1990). Discourse flaws in medical English Abstracts: A genre analysis per research- and text type. Text, 365-84.

Salager-Meyer, F. (1992). A text-type and move analysis study of verb tense and modality distribution in medical English Abstracts. English for Specific Purposes, 11, 93-113.

Swales, J. M (1986). A genre-based approach to language across the curriculum. In M. L. Tickoo (Ed.), language Across the Curriculum (pp.10-22). Singapore: RELC.

Swales, J. M. (1990). Genre analysis: English in academic and research settings. Cambridge: Cambridge University Press.

Swales, J. M. (2004). Research genres: explorations and applications. Cambridge: Cambridge University Press.

Thompson, D. (1993). Arguing for experimental "facts" in science. A study of research articles Results section in Biochemistry. Written Communication, 10(1), 106-128.

Ventola, E. (1992). Writing Scientific English: Overcoming intercultural problems. International Journal of Applied Linguistics, 2, $191-220$.

Yang, R., \& Allison, D. (2003). Research articles in applied linguistics: Moving from Results to Conclusions. English for Specific Purposes, 22, 365-385. 